\title{
Pentoxifylline improves insulin action limiting skeletal muscle catabolism after infection
}

\author{
T Vary $^{1,3}$, D Dardevet ${ }^{1}$, J Grizard ${ }^{1}$, L Voisin ${ }^{1}$, C Buffiere ${ }^{2}$, \\ P Denis $^{2}$, D Breuille ${ }^{2}$ and C Obled ${ }^{1}$ \\ ${ }^{1}$ Laboratoire d'Etude du Metabolisme Azote, Institut National de la Recherche Agronomique, Theix 63122 Ceyrat, France \\ ${ }^{2}$ Clintec Technologies, 78148 Velizy Cedex, France \\ ${ }^{3}$ Department of Cellular and Molecular Physiology, Penn State University College of Medicine, Hershey, Pennsylvania 10733, USA \\ (Requests for offprints should be addressed to T C Vary, Department of Cellular and Molecular Physiology, Penn State University College of Medicine, \\ Hershey, Pennsylvania 10733, USA)
}

\begin{abstract}
We investigated the ability of pentoxifylline (PTX) to modulate protein synthesis and degradation in the presence and absence of insulin during incubation of epitrochlearis muscle, 2 or 6 days after injection of Escherichia coli. On days 2 and 6 after infection, protein synthesis was inhibited by $25 \%$, whereas proteolysis was enhanced by $75 \%$. Insulin $(2 \mathrm{nM})$ in vitro stimulated protein synthesis in muscles from infected rats to the same extent as in controls. The ability of insulin to limit protein degradation was severely blunted $48 \mathrm{~h}$ after infection. On day 6 after infection, insulin inhibited proteolysis to a greater extent than on day 2. PTX suppressed the increase in plasma
\end{abstract}

concentrations of tumor necrosis factor more than 600-fold after injection of bacteria, and partially prevented the inhibition of protein synthesis and stimulation of protein degradation during sepsis. Moreover, PTX administration maintained the responsiveness of protein degradation to insulin during sepsis. Thus cytokines may influence skeletal muscle protein metabolism during sepsis, both indirectly through inhibition of the effects of insulin on proteolysis, and directly on the protein synthesis and degradation machinery.

Journal of Endocrinology (1999) 163, 15-24

\section{Introduction}

Insulin resistance in skeletal muscle characterizes the host's response to severe infection. Insulin regulates both glucose and protein metabolism in skeletal muscle. Both these metabolic processes show a resistance to the anabolic actions of insulin during sepsis. With respect to protein metabolism, proteolysis in skeletal muscle consistently shows a relative resistance to inhibition by insulin during the period immediately after a trauma (Tischler \& Fagan 1983) or during acute (16 h) peritonitis (Hasselgren et al. 1987, 1989). In contrast, the ability of insulin to enhance protein synthesis is variable in skeletal muscle during sepsis. During the period immediately after infection (up to $48 \mathrm{~h}$ ), insulin stimulates protein synthesis (Tischler \& Fagan 1983, Hasselgren et al. 1987, 1989), However, during chronic (5-day) intra-abdominal sepsis, insulin was without effect in augmenting skeletal muscle protein synthesis (Jurasinski et al. 1995a).

The intracellular mechanisms responsible for the development of insulin resistance have not been fully elucidated. The most likely explanation is a sepsis-induced block in cellular proteins associated with downstream effector molecules of insulin action. Insulin action is initiated by binding of the hormone to its high-affinity receptor located on the cell membrane. The binding of insulin to its receptor induces a conformational change in the receptor resulting in autophosphorylation of tyrosine residues of the $\beta$-subunit of the insulin receptor, and subsequent activation of tyrosine kinase activity. The tyrosine receptor kinase phosphorylates non-receptor intracellular proteins, including insulin receptor subunit (IRS)-1. Phosphorylation of IRS-1 on tyrosine residues provides a docking molecule for proteins involved in the signal transduction pathway for insulin (for review see White \& Kahn 1994, Avruch 1998).

Changes in the cellular abundance or phosphorylation state of the proteins involved in the signal transduction of insulin occur in other insulin-resistant states. In skeletal muscle, we (Vary et al. 1995) and others (Fan et al. 1996) have shown that neither the number of insulin receptors nor the binding of insulin to its receptor is responsible for the insulin resistance in sepsis. However, there is a marked decrease in the extent of tyrosine phosphorylation of the insulin receptor after in vivo insulin stimulation in endotoxin-treated rats (Fan et al. 1996). Likewise, the extent of phosphorylation of the IRS-1 in response to insulin is not increased. Thus the septic process affects 
proteins associated with the initial steps in the signal transduction pathway. Eventually, changes in the secondary signaling elements modulate effector molecules, thereby limiting the metabolic response to insulin.

With regard to the potential mediators responsible for the sepsis-induced insulin resistance, several lines of evidence indicate a potential link between tumor necrosis factor (TNF) and insulin resistance. First, plasma concentrations of TNF $\alpha$ are increased after infection (Chang \& Bistrian 1998). Secondly, TNF blocks the action of insulin through its ability to inhibit insulin receptor tyrosine kinase activity (Feinstein et al. 1993, Kroder et al. 1996, Peraldi et al. 1996, Peraldi \& Spiegelman 1998). Thirdly, obesity-induced insulin resistance is prevented in mice lacking a functional TNF response (Uysal et al. 1997). However, the ability of TNF to diminish the responsiveness of protein metabolism to insulin during sepsis remains unresolved.

One approach to understanding the role of TNF in initiating the metabolic response to infection is to inhibit its release or biological action, or both, during the bacterial insult. Administration of phosphodiesterase inhibitors, such as pentoxifylline (PTX) or amrinone, decreases the serum TNF $\alpha$ concentration in endotoxin-treated mice, rats and humans, and after induction of sepsis in rats (Doherty et al. 1991, Giroir \& Beutler 1992, Breuille et al. 1993, Jurasinski et al. 1995b). The ability of amrinone to abrogate sepsis-induced inhibition of protein synthesis (Jurasinski et al. 1995b) is similar to the effect of a specific TNF binding protein (Cooney et al. 1999) to do the same, suggesting that TNF may be the common mediator affected by both treatment modalities in a chronic intraperitoneal model of sepsis. The purpose of the present study was to examine whether or not suppression of TNFa secretion by PTX could enhance the ability of insulin to improve skeletal muscle protein balance during the anorexic ( 2 days after infection) and hypermetabolic (6 days after infection) phases after injection of bacteria. To assess the role of insulin independent of other hormones or cytokines in modulating protein metabolism during sepsis, we used epitrochlearis muscles incubated in vitro. We conclude that the improvement of insulin action on skeletal muscle protein metabolism after treatment with PTX is mediated primarily through modulation of proteolysis, rather than protein synthesis, after infection.

\section{Materials and Methods}

\section{Animals}

Four groups of animals were used to investigate the effect of infection or pentoxifylline treatment on protein metabolism in skeletal muscle: control, control treated with pentoxifylline (control+PTX), infected, and infected treated with pentoxifylline (infected+PTX). Male Sprague-Dawley rats $(250-300 \mathrm{~g})$ were individually housed in wire-bottom cages in a temperature-controlled environment $\left(22-23^{\circ} \mathrm{C}\right)$ with a 12 -h light : 12 -h darkness cycle. The infected group was produced by an injection of live Escherichia coli (0.6-0.9 $\times 10^{9}$ colony forming units/ rat) into the tail vein as described previously (Breuille et al. 1993, Voisin et al. 1996, Vary et al. 1998). Control rats received an equal volume of saline. After such injection of bacteria, a sepsis-like condition develops, as indicated by leukocytosis, an acute phase response, and sustained muscle catabolism (Breuille et al. 1993, Voisin et al. 1996, Vary et al. 1998); bacteremia is maintained for at least $48 \mathrm{~h}$ after injection of E. coli (Voisin et al. 1996).

Inhibition of TNF production after injection of bacteria was accomplished by pretreatment of infected rats with PTX (Doherty et al. 1991, Breuille et al. 1993). PTX $(100 \mathrm{mg} / \mathrm{kg}$ body weight) was injected intraperitoneally $1 \mathrm{~h}$ before the administration of E. coli (Breuille et al. 1993). Both control and infected rats received an equal volume of saline injected intraperitoneally at the time of the injection of PTX into infected rats. Blood samples $(0.2 \mathrm{ml})$ were withdrawn via the tail vein $90 \mathrm{~min}$ after injection of the E. coli or saline, for measurement of plasma TNF $\alpha$ concentrations. Plasma was separated from other cells by centrifugation and stored at $-80{ }^{\circ} \mathrm{C}$ until required for analysis for TNF $\alpha$.

During a 6-day period of acclimatization before injection of bacteria, all rats had access to water and food ad libitum. The diet consisted of a semisynthetic chow containing $12 \%$ protein, which has previously been shown to sustain normal growth (Breuille et al. 1993). Injection of live E. coli causes anorexia in this model (Breuille et al. 1993, Voisin et al. 1996, Vary et al. 1998). Therefore, control, control+PTX and infected + PTX rats were pairfed with respect to the untreated infected rats by estimating food intake based on previous studies and correcting the daily intake with the actual food consumption of the untreated infected group (Vary et al. 1998). Animals were offered food twice daily, at $0900 \mathrm{~h}$ and $1700 \mathrm{~h}$. All rats were fasted overnight before samples of muscles were taken for in vitro incubations. Animals were weighed on a daily basis. The experiments were carried out with the approval of animal care and use committees at both Institutions.

\section{Incubations of epitrochlearis muscles}

Epitrochlearis muscles were incubated in vitro as described previously (Stirewalt \& Low 1983, Stirewalt et al. 1985, Dardevet et al. 1994, 1996, 1998, Voisin et al. 1996, Vary et al. 1998). The epitrochlearis was chosen to examine protein turnover after injection of bacteria because previous reports have provided evidence that sepsis preferentially affects protein metabolism in muscles composed of mixed fast-twitch fibers (Hasselgren et al. 1989, Vary \& Kimball 1992, Cooney et al. 1994) and because its size 
renders it suitable for in vitro incubation. On the day of the experiment, rats were anesthetized with pentobarbital (50 $\mathrm{mg} / \mathrm{kg}$ body weight). The skin on each of the forelegs was removed. The epitrochlearis muscles were excised intact and immediately placed in Krebs-Henseleit bicarbonate buffer. The muscles were quickly rinsed and transferred to plastic tubes containing $2 \mathrm{ml}$ buffer. The tubes were capped and immediately oxygenated. One muscle from each rat was incubated under basal conditions (no hormones), while the contralateral muscle was incubated in the presence of insulin. Because incubations were performed on different days, muscles from control and infected rats incubated under basal conditions were always included, to allow for comparisons from one experiment to the next.

Epitrochlearis muscles were first preincubated for $30 \mathrm{~min}$. After the preincubation period, muscles were transferred to fresh media $(2 \mathrm{ml})$ and incubated for a further $180 \mathrm{~min}$, with a change of buffer every $60 \mathrm{~min}$. During the final $60 \mathrm{~min}$ of the incubation period, the buffer was supplemented with $0.5 \mathrm{mM}$ $\mathrm{L}-\left[{ }^{14} \mathrm{C}\right]$ phenylalanine $(0 \cdot 15 \mu \mathrm{Ci} / \mathrm{ml})$. At the end of the incubation, muscles were removed from the incubation buffer, trimmed of connective tissue, immersed into $2 \mathrm{ml}$ ice-cold 10\% (wt/vol) trichloroacetic acid (TCA), and weighed. The incubation medium was frozen and stored at $-20{ }^{\circ} \mathrm{C}$ until required for analysis of tyrosine and the specific radioactivity of phenylalanine.

The Krebs-Henseleit bicarbonate buffer consisted of $120 \mathrm{mM} \mathrm{NaCl}, 4 \cdot 8 \mathrm{mM} \mathrm{KCl}, 25 \mathrm{mM} \mathrm{NaHCO}, 2.5 \mathrm{mM}$ $\mathrm{CaCl}_{2}, 1.2 \mathrm{mM} \mathrm{KH} \mathrm{PO}_{4}, 1.2 \mathrm{mM} \mathrm{MgSO}_{4}(\mathrm{pH} 7 \cdot 4$ ) supplemented with $5 \mathrm{mM}$ glucose, $5 \mathrm{mM} 4-(2-$ hydroxylethyl)-1-piperineethanesulfonic acid, $0 \cdot 1 \%$ (wt/ vol) BSA, $0.17 \mathrm{mM}$ leucine, $0.20 \mathrm{mM}$ valine, $0.10 \mathrm{mM}$ isoleucine. Muscles were incubated at $37^{\circ} \mathrm{C}$ under an atmosphere of $95 \% \mathrm{O}_{2}-5 \% \mathrm{CO}_{2}$. In some experiments, $2 \mathrm{nM}$ insulin (Novo Pharmaceuticals, Bagsvaerd, Denmark) was added; we had previously established that $2 \mathrm{nM}$ was the minimum concentration of insulin that elicited a maximal stimulation of protein synthesis and an inhibition of proteolysis (Vary et al. 1998). Fresh dilutions of insulin were made on the day of the experiment, using Krebs-Henseleit buffer.

\section{Protein synthesis}

Rates of protein synthesis were estimated by the incorporation of radioactive phenylalanine into muscle protein. Muscles were homogenized in $2 \mathrm{ml} \mathrm{10 \%} \mathrm{TCA} \mathrm{using} \mathrm{a}$ Polytron PT10 set at $60 \%$ of maximal speed. The homogenate was centrifuged at $10000 \mathrm{~g}$ for $10 \mathrm{~min}$ at $4{ }^{\circ} \mathrm{C}$. The supernatant was decanted and the pellet washed three additional times with 10\% TCA to remove any acidsoluble radioactivity. The resulting pellet was dissolved in $1 \mathrm{M} \mathrm{NaOH}$ and incubated at $37^{\circ} \mathrm{C}$ for a minimum of $30 \mathrm{~min}$. Aliquots were assayed for protein using the bicinchoninic acid procedure (BCA, Pierce Chemicals, Rockford, IL, USA) according to the manufacturer's procedure, with crystalline BSA as a protein standard. Another aliquot was assayed for radioactivity by liquid scintillation spectrophotometry, using corrections for quenching (disintegrations/min). Rates of protein synthesis, expressed as nmol phenylalanine incorporated per $\mathrm{h}$ per mg protein, were calculated by dividing the amount of radioactivity incorporated into muscle protein over a 1-h period by the specific radioactivity of the phenylalanine in the incubation medium.

\section{Protein degradation}

Total protein degradation was estimated simultaneously with the rate of protein synthesis as the sum of the accumulation of tyrosine in the incubation buffer over a 1-h period plus the amount of tyrosine equivalents incorporated into protein via protein synthesis during the same time interval as described previously (Tischler \& Fagan 1983, Hasselgren et al. 1987, 1989, Dardevet et al. 1994, 1996, 1998, Voisin et al. 1996, Vary et al. 1998). Because tyrosine is neither synthesized nor metabolized by muscle, except for use by protein synthesis, the release of tyrosine from muscle into the incubation medium reflects net protein balance. To obtain the amount of tyrosine incorporated into mixed muscle proteins, we multiplied the values for incorporation of radioactive phenylalanine into protein by the molar ratio $(0.77)$ of tyrosine to phenylalanine in mixed proteins from skeletal muscle (Tischler \& Fagan 1983, Dardevet et al. 1994, 1996, 1998). Thus values for tyrosine equivalents incorporated into mixed muscle protein could be estimated for each individual muscle. Tyrosine in the incubation medium was measured fluorimetrically as described previously (Dardevet et al. 1994, 1996).

\section{Substrate assays}

TNF $\alpha$ in plasma samples was assayed with an ELISA kit (Genzyme, Boston, MA, USA) according to the manufacturer's instructions. Plasma samples were thawed only once, at the time of the assay for TNF $\alpha$. Duplicate determinations were performed for each plasma sample measurement. The sensitivity of detection for TNFa in rat plasma was $0.015 \mathrm{ng} / \mathrm{ml}$.

\section{Statistics}

The experimental data for each condition are expressed as means \pm s.E. for each group. The statistical evaluation of the data was performed using analysis of variance (ANOVA) to test for overall differences among groups, followed by the Sidak test for multiple comparisons to determine significance between means, only when the ANOVA indicated a significant difference among the 
group means. Differences among means were considered significant when $P<0 \cdot 05$.

\section{Results}

Effect of injection of PTX on protein synthesis and degradation in control rats

Before assessing the effects of treatment of infected rats with PTX, it was important to establish that PTX did not significantly alter protein synthesis or degradation in muscles from control rats. In these experiments, control rats were injected with either PTX or an equal volume of saline via the tail vein, as described in Materials and Methods. Food was restricted equally in both groups, to values obtained for infected rats (Breuille et al. 1993). Muscles were excised and incubated 2 or 6 days after injection of PTX. Rates of protein synthesis were lower in rats 2 days after injection of PTX (Fig. 1, top). By six days, rates of protein synthesis were not significantly different from each other in the basal condition between the groups (Fig. 1, top). Insulin (2 $\mathrm{nM}$ ) caused a similar stimulation of protein synthesis in each group, such that there were no significant differences between saline- and PTX-treated rats on either day. There were no significant differences in protein degradation in the basal condition between the two groups at either time point (Fig. 1, bottom). In saline-treated rats, insulin significantly $(P<0 \cdot 05)$ depressed proteolysis, by $20 \%$, on day 2 . Insulin limited proteolysis in PTX-treated rats by $24 \%$, although the decrease did not reach statistical significance $(P<0 \cdot 1)$. However, by day 6 , insulin significantly inhibited protein degradation to the same extent in saline- and PTX-treated control rats. Therefore, treatment of control rats with PTX caused only minor effects with respect to protein synthesis or proteolysis, either under basal conditions or after incubation with insulin, compared with saline-treated rats.

\section{Effect of infection and treatment with PTX on plasma TNFa concentrations}

In control rats, the plasma concentration of TNF $\alpha$ averaged $0.087 \pm 0.063 \mathrm{ng} / \mathrm{ml}(n=4)$. Ninety minutes after injection of bacteria, the plasma concentration of TNFa increased more than 600 -fold, to $55 \pm 6 \mathrm{ng} / \mathrm{ml}(n=10$; $P<0 \cdot 001$ compared with control). Plasma TNF $\alpha$ concentrations in untreated infected rats were similar to those observed in previous studies using this model of sepsis (Breuille et al. 1993). Administration of PTX before injection of bacteria suppressed the increase in plasma TNF $\alpha$ concentrations $(0 \cdot 78 \pm 0 \cdot 05 \mathrm{ng} / \mathrm{ml}, n=5 ; P<0 \cdot 001$ compared with non-treated infected rats). The mortality rate in untreated infected rats was approximately 15\% and was significantly reduced, to $5 \%$ (Fisher's exact test: $P<0.05$ compared with untreated infected rats) by pretreatment with PTX before injection of bacteria.

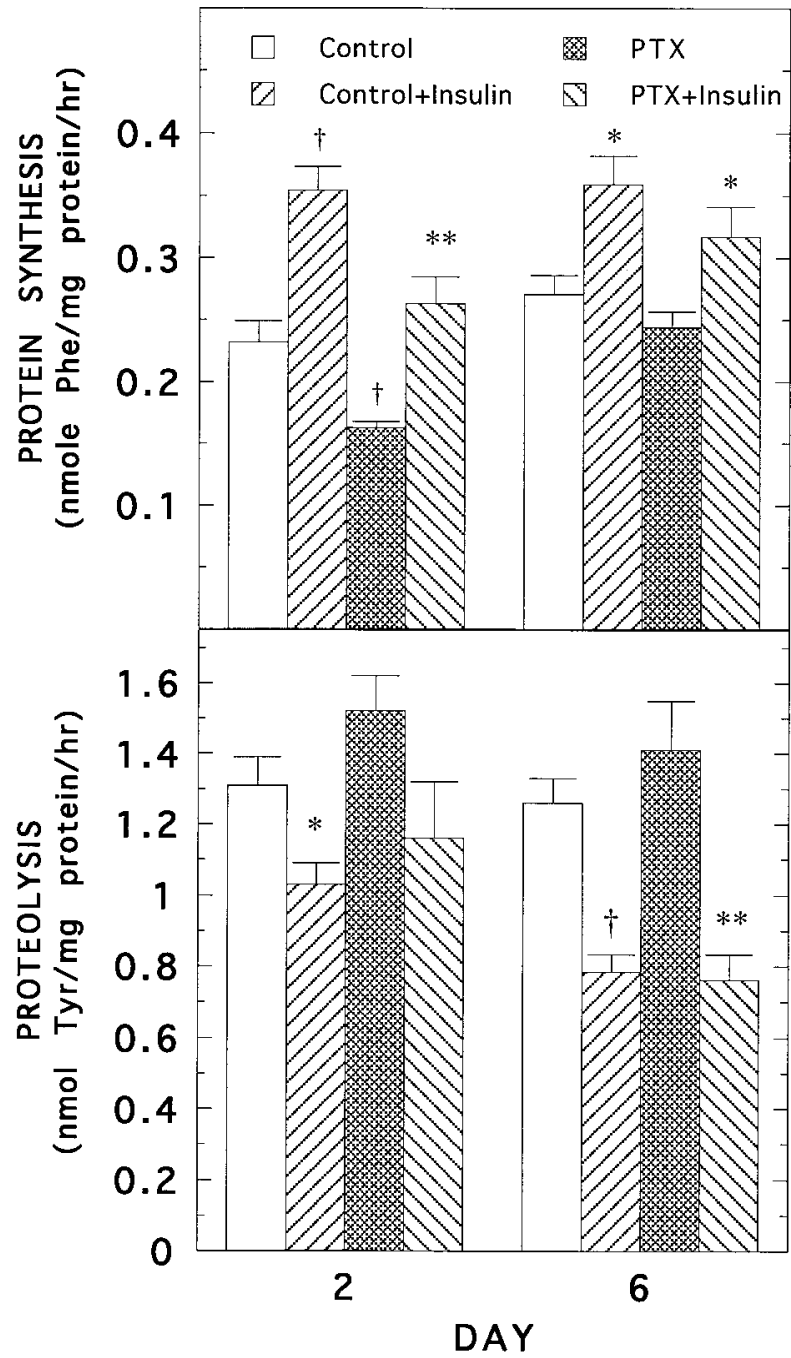

Figure 1 Effects of PTX on protein synthesis and proteolysis in control rats. Epitrochlearis muscles from control rats pair-fed to match the food consumption of infected rats were excised and incubated in vitro either 2 or 6 days after initiation of the feeding regimen in the presence or absence of insulin. In some animals, control rats were injected with PTX. Insulin was added to give a final concentration of $2 \mathrm{nM}$ in the incubation medium. Rates of protein synthesis and protein degradation were calculated as described in Materials and Methods. Values shown are means \pm S.E. for 3-14 muscles in each group. Protein synthesis Day 2 (ANOVA $F=16.73, P<0.001$ ), Day 6 (ANOVA $F=5.68$, $P<0.005),+P<0.001$ vs control, ${ }^{*} P<0.05$ vs basal condition of same group-insulin, ${ }^{*} P<0.01$ vs PTX. Proteolysis Day 2 (ANOVA $F=3.89, P<0.05$ ), Day 6 (ANOVA $F=15.92, P<0.001$ ), ${ }^{*} P<0.05$ vs control, $+P<0.001$ vs control, ${ }^{*} P<0.05$ vs PTX.

Food consumption and whole-body weight changes after infection Treatment of infected rats with PTX enhances food consumption after injection of bacteria (Breuille et al. 1993). However, protein metabolism is sensitive to nutritional status. Thus the possibility existed that the previous 


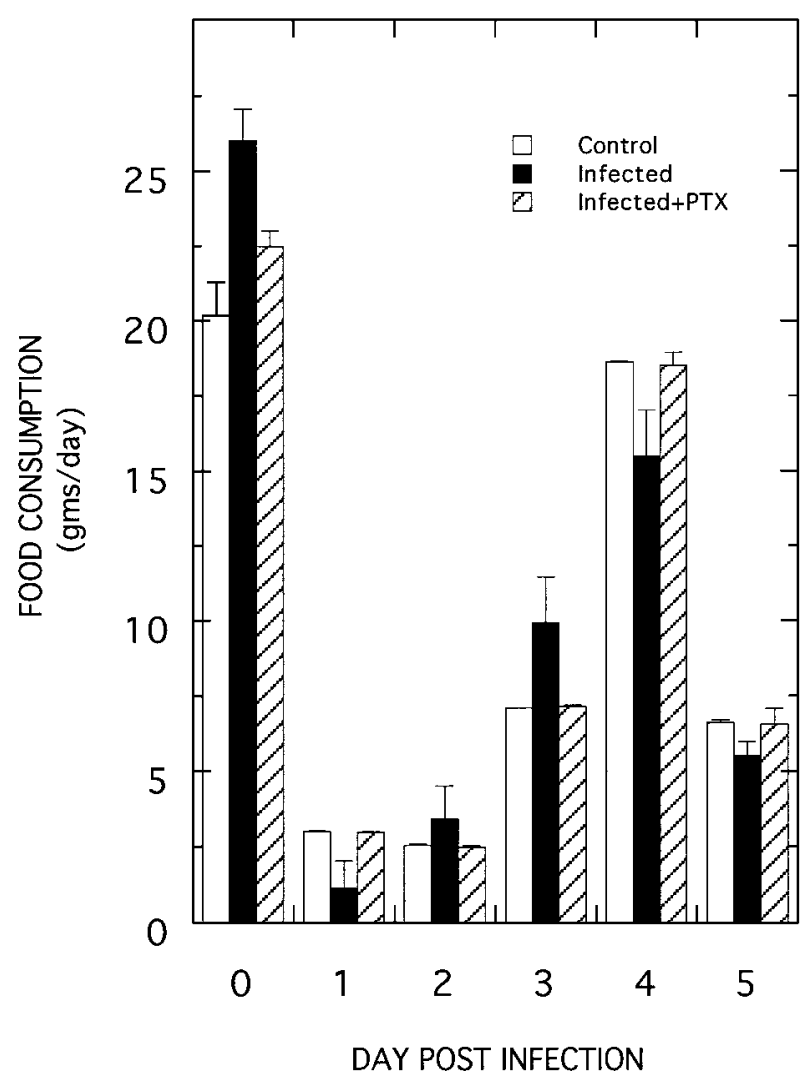

Figure 2 Food consumption in control, infected, and PTX-treated infected rats. Food consumption in control (open bars), infected (solid bars), and infected+PTX (striped bars) was measured during the first 5 days after injection of bacteria. Values shown are means \pm S.E. for $4-15$ animals in each group at each time point.

reports demonstrating an improvement in protein synthesis in infected rats treated with PTX could have resulted merely from increased food consumption (Breuille et al. 1993). To eliminate any alterations in protein metabolism resulting from a differential food intake between the experimental groups, all animals received the same amount of food. Hence, both control and infected rats treated with PTX were pair-fed with respect to the untreated infected rats. Figure 2 shows the food consumption in control, untreated infected, and infected rats treated with PTX. Essentially, all animals received the same nutrition throughout the course of the experiment. Figure 3 shows the effect of pair-feeding control and infected rats treated with PTX on the weight loss after injection of bacteria. When animals were pair-fed with respect to the untreated infected rats, no differences in the body weights were observed during the 4 days after infection between pair-fed control, pair-fed PTX-treated infected rats, and untreated infected rats. On day 5, however, the control rats did show a gain in weight that was not evident in the infected rats treated with PTX.

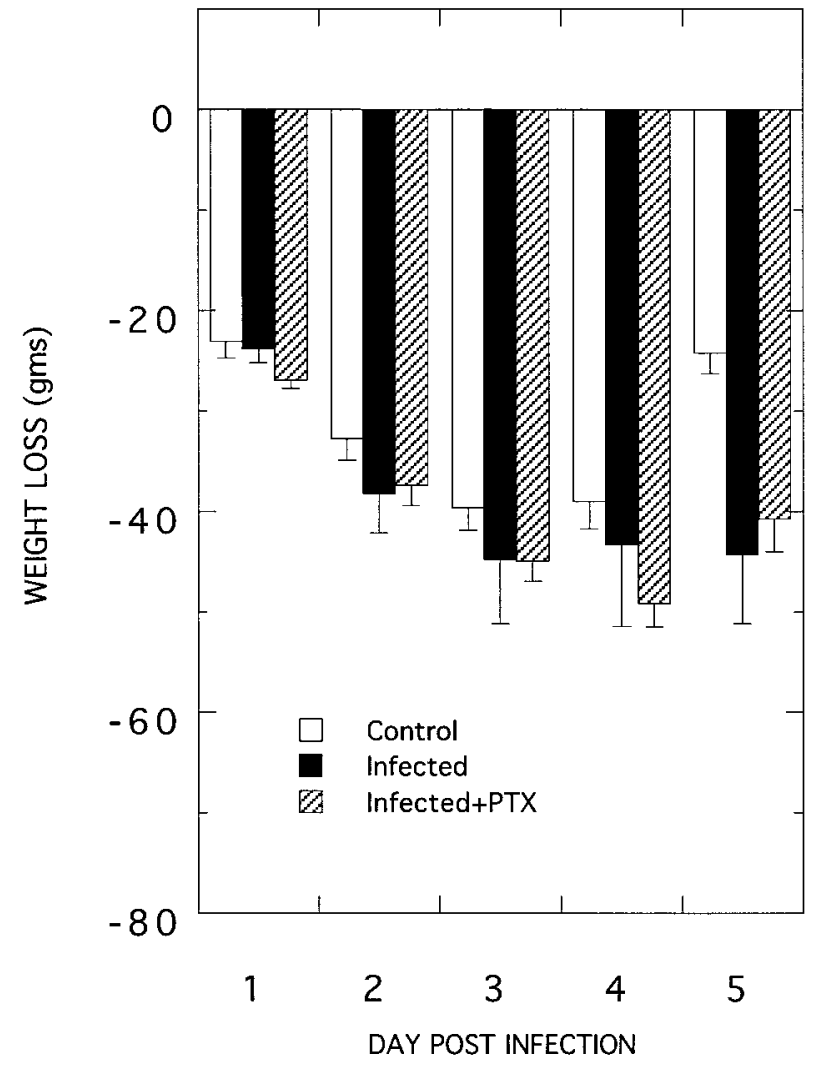

Figure 3 Cumulative weight changes in control, infected, and PTX-treated infected rats. The weight of rats from pair-fed control and infected groups described in Fig. 2 were measured daily. The differences in weight from day 0 are plotted. Values shown are means \pm S.E. for 5-15 animals in each group at each time point.

Table 1 Effect of food consumption and pentoxifylline on weight of epitrochlearis muscle after infection. Values are means \pm S.E.M. for 4-18 observations for each group at each day after infection

\begin{tabular}{|c|c|c|c|}
\hline & \multicolumn{3}{|c|}{ Muscle weight (mg) } \\
\hline & Control & Infected & $\begin{array}{l}\text { Infected }+ \\
\text { pentoxifylline }\end{array}$ \\
\hline Days after infection & & & \\
\hline 2 & $56 \pm 3$ & $44 \pm 2^{*}$ & $50 \pm 2$ \\
\hline 6 & $53 \pm 4$ & $36 \pm 2^{*}$ & $52 \pm 2$ \\
\hline
\end{tabular}

ANOVA Day 2: $F=5 \cdot 28, P<0 \cdot 005$. ANOVA Day 6: $F=25 \cdot 89, P<0 \cdot 001$ : ${ }^{*} P<0.05$ compared with Control or Infected + pentoxifylline for the same day after infection.

Effect of PTX on infection-induced reductions in epitrochlearis weights

The mass of the epitrochlearis in untreated infected rats was significantly reduced, by approximately $20 \%$, relative to pair-fed control rats 2 days after infection (Table 1). Pretreatment of infected rats with PTX prevented the loss of muscle mass. Likewise, the weight of the muscle from untreated infected rats was significantly reduced relative to 
control $(31 \%)$ or PTX-treated infected rats $(31 \%)$ on day 6 after infection. There were no significant differences in the weights of the epitrochlearis between infected rats treated with PTX and controls at either time. To understand better the mechanisms responsible for the alterations in epitrochlearis weights, we measured rates of protein synthesis and degradation.

Effect of PTX on protein synthesis during infection: modulation by insulin

Rates of protein synthesis in control, infected, and PTXtreated infected rats at 2 and 6 days after the injection of bacteria are shown in Fig. 4. On day 2 after infection, the rate of protein synthesis in muscles from untreated infected rats was significantly reduced, by $17 \%$ compared with controls $(0 \cdot 17 \pm 0 \cdot 01 \mathrm{nmol}$ Phe $/ \mathrm{mg}$ protein $/ \mathrm{h}, \quad n=12$ compared with $0.205 \pm 0.009 \mathrm{nmol} \mathrm{Phe} / \mathrm{mg}$ protein $/ \mathrm{h}$, $n=9 ; \quad P<0 \cdot 05$ ). Administration of PTX prevented the inhibition of protein synthesis observed in untreated infected rats $(0 \cdot 216 \pm 0 \cdot 01 \mathrm{nmol} \mathrm{Phe} / \mathrm{mg}$ protein $/ \mathrm{h}, n=13$ compared with $0.17 \pm 0.01 \mathrm{nmol} \mathrm{Phe} / \mathrm{mg}$ protein $/ \mathrm{h}$, $n=12 ; P<0 \cdot 05)$. Addition of insulin $(2 \mathrm{nM})$ to the incubation medium stimulated protein synthesis in all the groups (control without insulin 0.205 $\pm 0.009 \mathrm{nmol}$ $\mathrm{Phe} / \mathrm{mg}$ protein/h, $n=9$ compared with control+insulin $0 \cdot 354 \pm 0 \cdot 019 \mathrm{nmol}$ Phe $/ \mathrm{mg}$ protein $/ \mathrm{h}, n=11, P<0 \cdot 001$; infected without insulin $0.17 \pm 0.01 \mathrm{nmol} \mathrm{Phe} / \mathrm{mg}$ protein $/ \mathrm{h}, \quad n=12$ compared with infected + insulin $0 \cdot 315 \pm 0 \cdot 022 \mathrm{nmol} \mathrm{Phe} / \mathrm{mg}$ protein $/ \mathrm{h}, n=10, P<0 \cdot 001$; infected + PTX $0 \cdot 216 \pm 0.01 \mathrm{nmol} \mathrm{Phe} / \mathrm{mg}$ protein $/ \mathrm{h}$, $n=13$ compared with infected $+\mathrm{PTX}+$ insulin $0.345 \pm$ $0 \cdot 017 \mathrm{nmol}$ Phe $/ \mathrm{mg}$ protein $/ \mathrm{h}, n=8, P<0 \cdot 001)$. The magnitude of the stimulation of protein synthesis in muscles incubated with insulin was the same in each of the groups examined.

On day 6 after infection, the rate of protein synthesis remained depressed in untreated infected rats compared with controls $(0 \cdot 170 \pm 0 \cdot 007 \mathrm{nmol} \mathrm{Phe} / \mathrm{mg}$ protein $/ \mathrm{h}$, $n=13$ compared with $0.229 \pm 0.009 \mathrm{nmol} \mathrm{Phe} / \mathrm{mg}$ protein/h, $n=1, \quad P<0 \cdot 001$; Fig. 4). Protein synthesis under basal conditions was not significantly increased in muscles of infected rats treated with PTX compared with untreated septic rats $(0 \cdot 170 \pm 0.007 \mathrm{nmol} \mathrm{Phe} / \mathrm{mg}$ protein $/ \mathrm{h}, \quad n=13$ compared with $0 \cdot 208 \pm 0.008 \mathrm{nmol}$ $\mathrm{Phe} / \mathrm{mg}$ protein/h, $n=12)$. Addition of insulin $(2 \mathrm{nM})$ to the incubation medium stimulated protein synthesis in all the groups (control without insulin 0.229 $\pm 0.009 \mathrm{nmol}$ $\mathrm{Phe} / \mathrm{mg}$ protein $/ \mathrm{h}, n=10$ compared with control+insulin $0 \cdot 359 \pm 0 \cdot 019 \mathrm{nmol} \mathrm{Phe} / \mathrm{mg}$ protein $/ \mathrm{h}, n=11, P<0 \cdot 001$; infected without insulin $0.170 \pm 0.007 \mathrm{nmol} \mathrm{Phe} / \mathrm{mg}$ protein $/ \mathrm{h}, n=13$ compared with infected+insulin $0 \cdot 314 \pm$ $0.009 \mathrm{nmol} \mathrm{Phe} / \mathrm{mg}$ protein $/ \mathrm{h}, \quad n=10, \quad P<0.001$; infected + PTX $0 \cdot 208 \pm 0 \cdot 008 \mathrm{nmol} \mathrm{Phe} / \mathrm{mg}$ protein $/ \mathrm{h}$, $n=12$ compared with infected $+\mathrm{PTX}+$ insulin $0 \cdot 294 \pm$ 0.012 nmol Phe $/ \mathrm{mg}$ protein $/ \mathrm{h}, n=6, P<0 \cdot 001)$. The

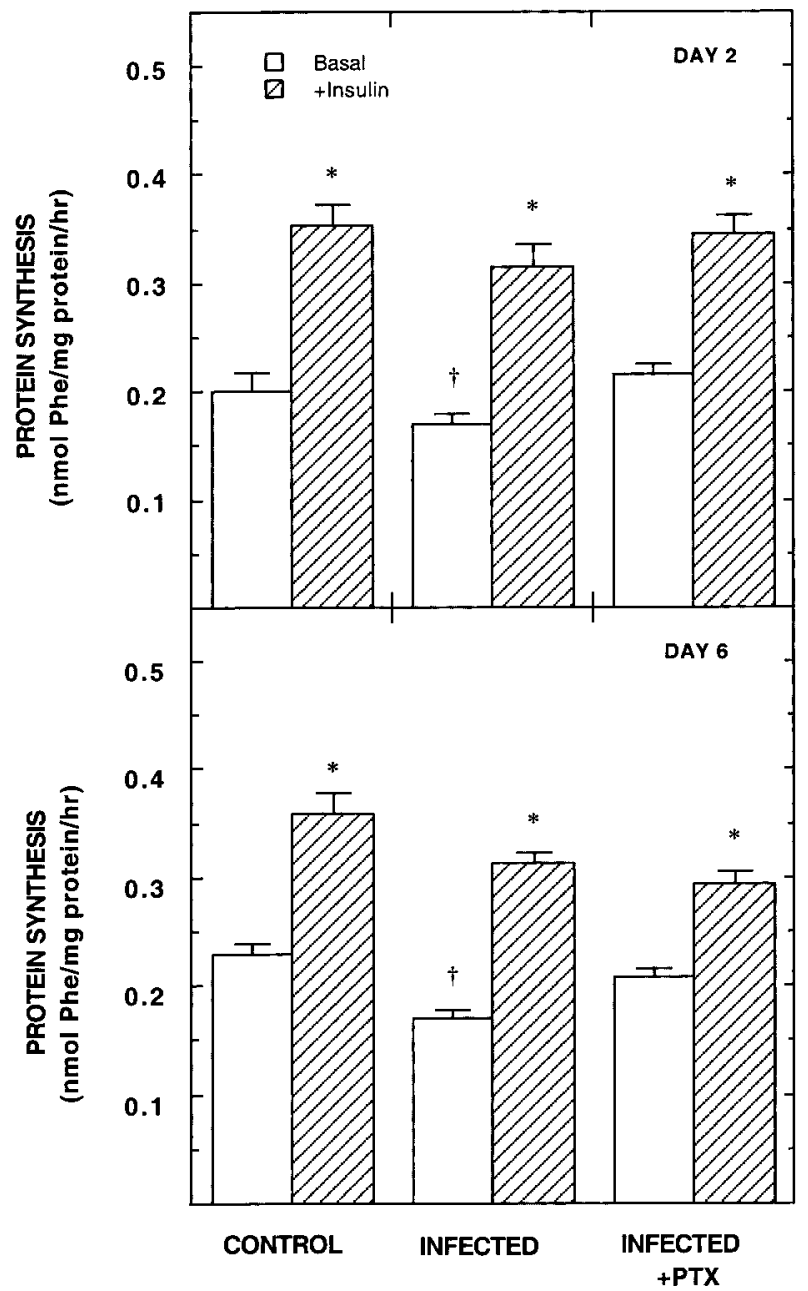

Figure 4 Rates of protein synthesis in control, infected, and PTX-treated infected rats on day 2 and day 6 after infection: effects of insulin. Epitrochlearis muscles from infected and pair-fed control and PTX-treated infected rats were excised and incubated in vitro 2 days or 6 days after injection of bacteria as described in Fig. 1, in the presence or absence of insulin. Insulin was added to give a final concentration of $2 \mathrm{nM}$ in the incubation medium. Rates of protein synthesis were calculated as described in Fig. 1. Values shown are means \pm S.E. for $6-13$ muscles in each group. Day 2 (ANOVA $F=25 \cdot 2 ; P<0 \cdot 001$ ): ${ }^{*} P<0.001$ compared with same group under basal incubation conditions; $+P<0.05$ compared with control or infected+PTX under basal conditions. Day 6 (ANOVA $F=88.97 ; P<0.001$ ): ${ }^{*} P<0.001$ compared with same group under basal incubation conditions; $+P<0 \cdot 01$ compared with control under basal conditions.

maximal rate of protein synthesis in muscles incubated with insulin was the same in each of the groups examined.

\section{Effect of PTX on protein degradation during infection: modulation by insulin}

Under basal conditions, protein degradation was enhanced by $50 \%$ in infected rats on day 2 after infection compared 


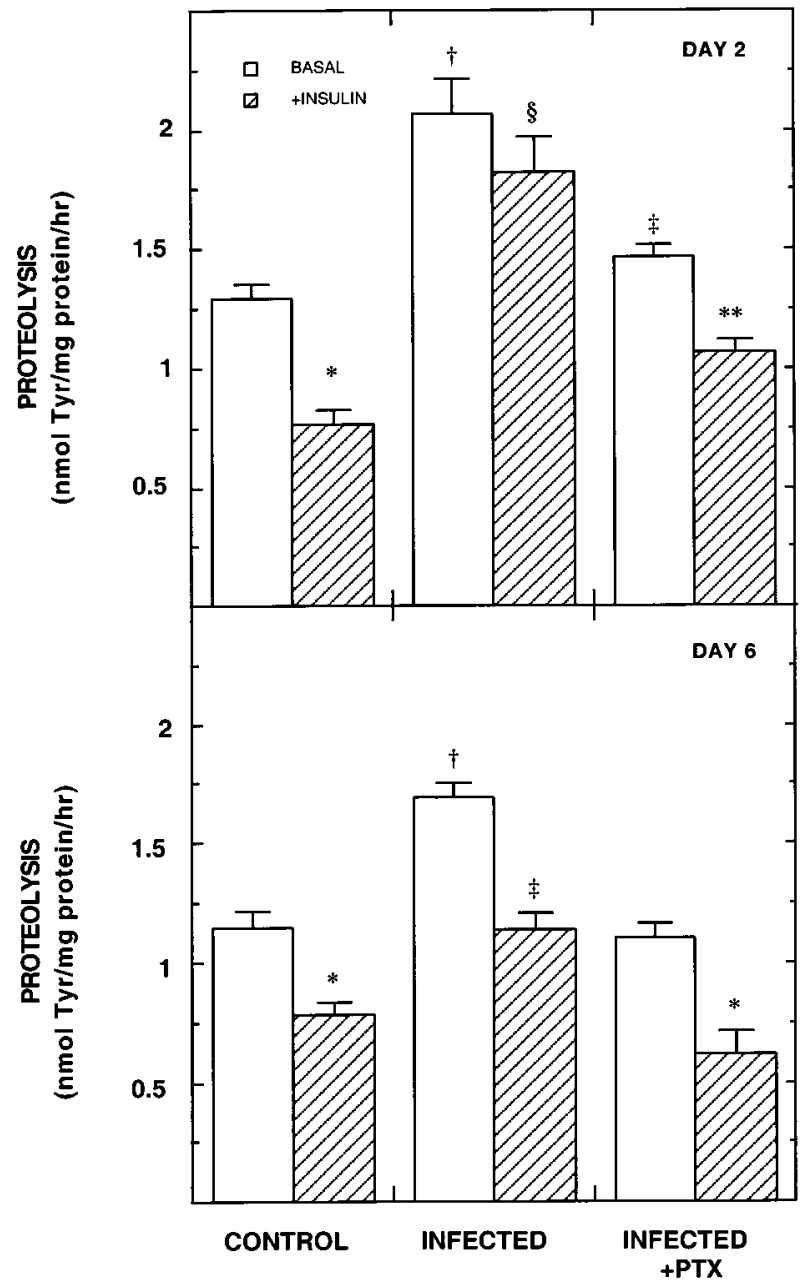

Figure 5 Rates of protein degradation in control, infected, and PTX-treated infected rats on day 2 or day 6 after infection: effects of insulin. Epitrochlearis muscles from infected and pair-fed control and PTX-treated infected rats were excised and incubated in vitro 2 days or 6 days after injection of bacteria as described in Fig. 4 , in the presence or absence of insulin. Insulin was added to give a final concentration of $2 \mathrm{nM}$ in the incubation medium. Rates of protein synthesis were calculated as described in Fig. 1. Values shown are means \pm S.E. for 4-14 muscles in each group. Day 2 (ANOVA $F=14.70 ; P<0.001$ ): ${ }^{*} P<0.005$ compared with control basal conditions; ${ }^{* *} P<0.05$ compared with infected+PTX basal conditions or control +insulin; $+P<0.005$ compared with control or infected+PTX, basal conditions; $\neq P<0.005$ compared with control+ insulin or infected +PTX+insulin. Day 6 (ANOVA $\S F=24 \cdot 01$; $P<0.001$ ): ${ }^{*} P<0.01$ compared with same group under basal incubation conditions; $\uparrow P<0.001$ compared with control or infected+PTX, basal conditions; $\ddagger P<0.01$ compared with control+ insulin or infected+PTX+insulin.

with controls $(2 \cdot 07 \pm 0 \cdot 014 \mathrm{nmol} \mathrm{Tyr} / \mathrm{mg}$ protein $/ \mathrm{h}$, $n=12$ compared with $1.29 \pm 0.06 \mathrm{nmol} \mathrm{Tyr} / \mathrm{mg}$ protein/h, $n=8, P<0 \cdot 001$; Fig. 5). The rate of protein degradation was significantly reduced in PTX-treated infected rats compared with untreated infected rats controls $(1.47 \pm 0.005 \mathrm{nmol} \mathrm{Tyr} / \mathrm{mg}$ protein $/ \mathrm{h}, \quad n=13$ compared with $2.07 \pm 0.014 \mathrm{nmol} \mathrm{Tyr} / \mathrm{mg}$ protein/h, $n=12 ; P<0 \cdot 001)$. There were no significant differences in protein degradation between control and PTX-treated rats.

In controls, incubation of muscles with $2 \mathrm{nM}$ insulin inhibited proteolysis by approximately 35\% (0.763 \pm $0.07 \mathrm{nmol} \mathrm{Tyr} / \mathrm{mg}$ protein $/ \mathrm{h}, n=4$ compared with $1 \cdot 29 \pm$ $0.06 \mathrm{nmol} \mathrm{Tyr} / \mathrm{mg}$ protein $/ \mathrm{h}, n=8 ; P<0 \cdot 05)$. Unlike its effect in control animals, insulin did not significantly reduce proteolysis in muscles from infected rats $(1 \cdot 82 \pm 0.15 \mathrm{nmol} \mathrm{Tyr} / \mathrm{mg}$ protein $/ \mathrm{h}, n=10$ compared with $2 \cdot 07 \pm 0 \cdot 014 \mathrm{nmol} \mathrm{Tyr} / \mathrm{mg}$ protein/h, $n=12$ ), indicating an insulin resistance. In the presence of insulin, proteolysis was increased approximately $2 \cdot 4$-fold in muscles from infected rats compared with controls $(1.82 \pm 0.15 \mathrm{nmol} \mathrm{Tyr} / \mathrm{mg}$ protein $/ \mathrm{h}, n=10$ compared with $0.763 \pm 0.07 \mathrm{nmol} \mathrm{Tyr} / \mathrm{mg}$ protein $/ \mathrm{h}, \quad n=4$; $P<0 \cdot 001)$. The ability of insulin to inhibit protein degradation was partially restored by treatment of infected rats with PTX. Incubation of muscles from PTX-treated infected rats with medium containing insulin resulted in a $25 \%$ inhibition in protein degradation $(1.07 \pm 0.05 \mathrm{nmol}$ $\mathrm{Tyr} / \mathrm{mg}$ protein $/ \mathrm{h}, n=7$ compared with $1 \cdot 47 \pm 0 \cdot 05 \mathrm{nmol}$ $\mathrm{Tyr} / \mathrm{mg}$ protein $/ \mathrm{h} ; P<0 \cdot 001)$. However, protein degradation in the presence of insulin remained significantly increased, by $40 \%$, compared with controls $(1.07 \pm$ $0.05 \mathrm{nmol} \mathrm{Tyr} / \mathrm{mg}$ protein $/ \mathrm{h}, \quad n=7$ compared with $0.763 \pm 0.07 \mathrm{nmol}$ Tyr/mg protein $/ \mathrm{h} ; P<0.05)$.

The rate of protein degradation in epitrochlearis muscle from infected rats decreased on day 6 after infection relative to day $2(1.69 \pm 0.067 \mathrm{nmol} \mathrm{Tyr} / \mathrm{mg}$ protein $/ \mathrm{h}$, $n=10$ compared with $2 \cdot 07 \pm 0 \cdot 014 \mathrm{nmol} \mathrm{Tyr} / \mathrm{mg}$ protein $/ \mathrm{h}, n=12 ; P<0 \cdot 05)$, but remained increased compared with controls under basal conditions on day 6 $(1.69 \pm 0.067 \mathrm{nmol} \mathrm{Tyr} / \mathrm{mg}$ protein $/ \mathrm{h}, n=10$ compared with $1.15 \pm 0.0068 \mathrm{nmol} \mathrm{Tyr} / \mathrm{mg}$ protein $/ \mathrm{h}, \quad n=8$, $P<0 \cdot 001$; Fig. 5). Administration of PTX to infected rats significantly reduced protein degradation, by $35 \% \mathrm{com}-$ pared with untreated infected rats $(1.69 \pm 0.067 \mathrm{nmol}$ Tyr $/ \mathrm{mg}$ protein/h, $n=10$ compared with $1 \cdot 10 \pm$ $0 \cdot 0061 \mathrm{nmol} \mathrm{Tyr} / \mathrm{mg}$ protein $/ \mathrm{h}, n=11 ; P<0 \cdot 001)$. There were no significant differences in proteolysis between PTX-treated infected rats and controls $(1 \cdot 15 \pm 0 \cdot 0068$ nmol Tyr/mg protein $/ \mathrm{h}, n=8$ compared with $1 \cdot 10 \pm$ 0.0061 $\mathrm{nmol} \mathrm{Tyr} / \mathrm{mg}$ protein/h, $n=11$ ).

In controls, insulin reduced proteolysis compared with basal conditions $(0.785 \pm 0.049 \mathrm{nmol} \mathrm{Tyr} / \mathrm{mg}$ protein $/ \mathrm{h}$, $n=14$ compared with $1 \cdot 15 \pm 0.068 \mathrm{nmol} \mathrm{Tyr} / \mathrm{mg}$ protein $/ \mathrm{h}, n=8 ; P<0 \cdot 001)$. Unlike it effects on day 2 , insulin significantly reduced protein degradation in muscles from rats 6 days after injection with bacteria $(1.14 \pm 0.07 \mathrm{nmol} \mathrm{Tyr} / \mathrm{mg}$ protein $/ \mathrm{h}, n=10$ compared with $1.69 \pm 0.067 \mathrm{nmol} \mathrm{Tyr} / \mathrm{mg}$ protein $/ \mathrm{h}, \quad n=10$; $P<0 \cdot 001)$. However, rates of protein degradation in infected rats remained more than 50\% greater compared 
with muscles from controls incubated in the presence of insulin $(1.14 \pm 0.07 \mathrm{nmol} \mathrm{Tyr} / \mathrm{mg}$ protein $/ \mathrm{h}, n=10 \mathrm{com}-$ pared with $0.785 \pm 0.049 \mathrm{nmol} \mathrm{Tyr} / \mathrm{mg}$ protein $/ \mathrm{h}, n=14$; $P<0 \cdot 005)$. Incubation of muscles from PTX-treated infected rats with medium containing insulin resulted in a $50 \%$ inhibition in protein degradation $(0.617 \pm$ $0.099 \mathrm{nmol} \mathrm{Tyr} / \mathrm{mg}$ protein $/ \mathrm{h}, n=6$ compared with $1 \cdot 10 \pm 0 \cdot 061 \mathrm{nmol} \mathrm{Tyr} / \mathrm{mg}$ protein $/ \mathrm{h}, n=11 ; P<0 \cdot 001)$. Unlike on day 2, on day 6 there were no significant differences between infected rats treated with PTX and controls in the presence of insulin $(0.617 \pm 0.099 \mathrm{nmol}$ $\mathrm{Tyr} / \mathrm{mg}$ protein/h, $n=6$ compared with $0.785 \pm$ $0.049 \mathrm{nmol} \mathrm{Tyr} / \mathrm{mg}$ protein/h, $n=14)$.

\section{Conclusions}

Insulin resistance is defined as a smaller than normal response to a given dose of insulin. In the present study, inhibition of proteolysis by insulin was reduced in skeletal muscle after infection, indicating an insulin resistance. However, knowledge of the basis of the insulin resistance after infection is very incomplete. By analogy with obesity, cytokines such as TNF may limit the ability of insulin to modulate cellular metabolism (Hotamisligil \& Spiegelman 1994). Likewise, there is evidence that TNF participates in the regulation of protein turnover in skeletal muscle in vivo (Cooney et al. 1999) or human myoblasts in culture (Frost et al. 1997). In the present set of investigations, we sought to determine the effect of limiting TNF $\alpha$ expression on the ability of insulin to modulate protein metabolism. Pretreatment of rats injected with live bacteria with PTX suppressed the appearance of TNF in the plasma by 98\%. Reducing plasma TNF concentrations improved the sensitivity of proteolysis to insulin after infection compared with untreated infected rats. Rates of protein degradation decreased by more than $50 \%$ after addition of insulin to the incubation medium in septic rats treated with PTX, whereas muscles from untreated infected rats were relatively unresponsive to the inhibitory effects of insulin. Therefore, administration of PTX reduced the development of insulin resistance with respect to protein degradation after infection. The association of reduced TNF concentrations coupled with an enhanced ability of insulin to inhibit proteolysis suggests that TNF has a central role in the development of insulin resistance after infection. However, we cannot exclude the possibility that PTX modulates protein metabolism in septic rats by some mechanism unrelated to inhibition of TNF $\alpha$ expression.

The effect of PTX on the ability of insulin to limit protein degradation and stimulate protein synthesis after infection may result from a direct effect of TNF on skeletal muscle or indirectly via substances produced by other cells or tissues sensitive to TNF. These two possibilities are not mutually exclusive. The effect of PTX was observed after only a single dose of the compound, indicating that PTX suppresses the compound(s) responsible for initiation of the insulin resistance during the period immediately after injection of the live bacteria. Treatment of control animals with PTX did not affect epitrochlearis weight, protein synthesis, or protein degradation appreciably, indicating that PTX appears not to exert a non-specific effect on skeletal muscle protein metabolism in the absence of infection. However, caution must be exercised in ascribing the metabolic effects of PTX on protein metabolism in muscle. TNF stimulates the secretion of other cytokines, including interleukins-1 and -6 and other inflammatory mediators. Furthermore, TNF often acts in synergy with other cytokines. However, our results are at least consistent with the hypothesis that modulation of TNF $\alpha$ by PTX may mediate changes in muscle protein metabolism after a bacterial challenge.

Pretreatment with PTX of rats injected with live bacteria prevented the loss of epitrochlearis mass on either day 2 or day 6 after infection. Presumably, alteration in the rates of protein synthesis or protein degradation were responsible for the increase in muscle weight in septic rats treated with PTX during sepsis. Rates of protein synthesis tended to be greater in PTX-treated septic rats, but were only significantly increased in muscles from infected rats treated with PTX on day 2 after infection. In contrast, PTX treatment prevented the stimulated proteolysis observed in infected rats on day 2 after infection. However, administration of PTX did not completely prevent the acceleration of protein degradation after infection. Zamir et al. (1992) reported that muscle protein breakdown was also reduced, but not normalized, after infusion of polyclonal antibodies raised against TNF into acutely infected rats. During the hypermetabolic phase of sepsis, PTX administration in infected rats completely prevented the enhanced proteolysis in muscle compared with untreated infected rats. These findings provide evidence that a decreased rate of protein degradation appeared primarily responsible for the maintenance of the muscle mass in septic rats treated with PTX during the anorexic and hypermetabolic period. Furthermore, a part of the proteinsparing effects of PTX results from its ability to abrogate the inhibitory effects of infection on protein synthesis and stimulatory effects on proteolysis.

Previous studies from this laboratory suggested the effects of PTX on protein synthesis measured in vivo 2 days after infection were independent of food consumption (Breuille et al. 1993). However, in those studies, infected rats treated with PTX were never pair-fed with respect to the non-treated infected rats. The nutritional status of animals and man has long been known to modulate both protein synthesis and protein degradation. Thus the possibility exists that the effects of PTX in the previous report (Breuille et al. 1993) were related simply to increased food consumption during periods immediately after the injection of bacteria. To eliminate the influence of increased food consumption in the present study, PTX-treated 
infected rats were pair fed to the food consumption of the untreated septic rats. The results obtained from pairfeeding PTX-treated septic rats to the same level of food intake as untreated septic rats was essentially that observed when PTX-treated rats were allowed to feed ad libitum. Therefore, the ability of PTX to limit the inhibition of protein synthesis and stimulation of protein degradation during sepsis are independent of food intake over the first 5 days after infection. Thus the effect of PTX to partially prevent the alterations in the regulation of protein turnover during sepsis appears not to be dependent on food intake.

In summary, our study brings new insights into the relationship between TNF and the ability of insulin to promote anabolism in skeletal muscle after infection. Data from the present study indicate that infection produces fundamental defects in skeletal muscle protein synthesis and proteolysis that are independent of the food intake or nutritional state of the animal. Administration of PTX can partially prevent the inhibition of protein synthesis in infected rats during the anorexic phase of sepsis. Treatment of septic rats with PTX prevented the stimulation of proteolysis. Furthermore, PTX treatment abolished the insulin resistance with respect to proteolysis and restored the responsiveness of protein degradation to inhibition by insulin after infection. Because PTX administration suppressed the increase in plasma TNF $\alpha$ concentrations after infection, these data suggest that this cytokine has an important role in the regulation of protein turnover during sepsis.

\section{Acknowledgements}

The authors wish to thank C Sornet for expert technical assistance, and the Center for Biostatistics and Epidemiology of the Pennsylvania State University College of Medicine for their expertise in the statistical evaluation of the studies. This study was supported by Clintec Technologies, France, the Institut National de la Recherché Agronomique, and Grant GM 39277 from the United States Public Health Service National Institute of General Medical Sciences.

\section{References}

Avruch J 1998 Insulin signal transduction through protein kinase cascades. Molecular and Cellular Biochemistry 182 31-42.

Breuille D, Farge M, Rose R, Arnal M \& Obled C 1993 Pentoxifylline decreases the body weight loss and muscle protein wasting characteristic of sepsis. American Journal of Physiology 265 E660-E666.

Chang H \& Bistrian B 1998 The role of cytokines in the catabolic consequences of infection and injury. Journal of Parenteral and Enteral Nutrition 22 156-166.

Cooney R, Owens E, Jurasinski C, Gray K, Vannice J \& Vary T 1994 Interleukin-1 receptor antagonist prevents sepsis-induced inhibition of protein synthesis. American Journal of Physiology 267 E636-E641.

Cooney R, Kimball SR, Eckman R, Maish III G, Shumate M \& Vary TC 1999 TNF-binding protein ameliorates inhibition of skeletal muscle protein synthesis during sepsis. American Journal of Physiology 276 E611-E619.

Dardevet D, Sornet C, Attaix D, Baracos VE \& Grizard J 1994 Insulin-like growth factor-I and insulin resistance in skeletal muscle of adult and old rats. Endocrinology 134 1475-1484.

Dardevet D, Sornet C, Vary T \& Grizard J 1996 Phosphatidylinositol 3-phosphate and p70 S6 kinase participate in the regulation of protein turnover in skeletal muscle by insulin and insulin-like growth factor-I. Endocrinology 134 4089-4094.

Dardevet D, Sornet C, Savary I, Debras E, Patureau-Mirand P \& Grizard J 1998 Glucocorticoids effects on insulin- and IGF-Iregulated muscle protein metabolism during aging. Journal of Endocrinology 156 83-89.

Doherty G, Jensen J, Alexander H, Buresh C \& Norton J 1991 Pentoxifylline suppression of tumor necrosis factor gene transcription. Surgery 111 192-198.

Fan J, Li Y, Wojnar M \& Lang C 1996 Endotoxin-induced alterations in insulin-stimulated phosphorylation of insulin-receptor, IRS-1, and MAP kinase in skeletal muscle. Shock 6 164-170.

Feinstein R, Kanety H, Papa M, Lunenfeld B \& Karasik A 1993 Tumor necrosis factor- $\alpha$ suppresses insulin-induced tyrosine phosphorylation of insulin receptor and its substrates. Journal of Biological Chemistry 268 26055-26058.

Frost RA, Lang CH \& Gelato MC 1997 Transient exposure of human myoblasts to tumor necrosis factor- $\alpha$ inhibits serum and insulin-like growth factor-I stimulated protein synthesis. Endocrinology 138 4153-4159.

Giroir B \& Beutler B 1992 Effect of amrinone on tumor necrosis factor production in endotoxic shock. Circulatory Shock $\mathbf{3 6}$ 200-207.

Hasselgren PO, Warner BW, James JH, Takehara H \& Fischer JE 1987 Effect of insulin on amino acid uptake and protein turnover in skeletal muscle from septic rats. Evidence for insulin resistance of protein breakdown. Archives of Surgery 122 228-233.

Hasselgren PO, James JH, Benson DW, Hall-Angeras M, Angeras U, Hiyama DT, Li S \& Fischer JE 1989 Total and myofibrillar protein breakdown in different types of rat skeletal muscle: effects of sepsis and regulation by insulin. Metabolism 38 6334-6340.

Hotamisligil G \& Spiegelman B 1994 Tumor necrosis factor $\alpha$ : a key component of the obesity-diabetes link. Diabetes 43 12711278.

Jurasinski C, Gray K \& Vary TC 1995a Modulation of skeletal muscle protein synthesis by amino acids and insulin during sepsis. Metabolism 44 1130-1138.

Jurasinski C, Kilpatrick L \& Vary T 1995 b Amrinone prevents muscle protein wasting during chronic sepsis. American Journal of Physiology 268 E491-E500.

Kroder G, Bossenmayer B, Kellerer M, Capp E, Stoyanov B, Muhlhofer A, Berti L, Horikoski H, Ullrich A \& Naring H 1996 Tumor necrosis factor- $\alpha$ and hyperglycemia-induced insulin resistance: evidence for different mechanisms and different effects on insulin signaling. Journal of Clinical Investigation 97 1471-1477.

Peraldi P \& Spiegelman B 1998 TNF- $\alpha$ and insulin resistance: summary and future prospects. Molecular and Cellular Biochemistry 189 169-175.

Peraldi P, Hotamisligil G, Buurman W, White M \& Spiegelman B 1996 Tumor necrosis factor (TNF)- $\alpha$ inhibits insulin signaling through stimulation of the $\mathrm{p} 55$ receptor and activation of sphingomyelinase. Journal of Biological Chemistry 271 13018-13022.

Stirewalt WS \& Low RB 1983 Effects of insulin on protein turnover in rat epitrochlearis muscle. Biochemical Journal 210 $323-330$ 
Stirewalt WS, Low RB \& Slaiby JM 1985 Insulin sensitivity and responsiveness of epitrochlearis and soleus muscle from fed and starved rats. Biochemical Journal 227 355-362.

Tischler M \& Fagan J 1983 Response to trauma and protein, amino acid, and carbohydrate metabolism in injured and uninjured rat skeletal muscle. Metabolism 32 853-868.

Uysal T, Wiesbach S, Marino M \& Hotamisligil G 1997 Protection from obesity-induced insulin-resistance in mice lacking TNF- $\alpha$ function. Nature 389 600-614.

Vary TC \& Kimball SR 1992 Sepsis-induced changes in protein synthesis: differential effects on fast- and slow-twitch muscles. American Journal of Physiology 262 C1513-C1519.

Vary T, Drnevich D, Jurasinsk C \& Brennan W 1995 Mechanisms regulating skeletal muscle glucose metabolism in sepsis. Shock 3 403-410.

Vary T, Dardevet D, Grizard J, Voisin L, Buffiere C, Denis P, Brueille D \& Obled C 1998 Differential regulation of skeletal muscle protein turnover by insulin and IGF-I following bacteremia. American Journal of Physiology 275 E584-E593.

Voisin L, Breuille D, Combaret L, Pouyet C, Taillandier D, Aurousseau E, Obled C \& Attaix D 1996 Muscle wasting in a rat model of long-lasting sepsis results from activation of lysosomal, $\mathrm{Ca}^{2+}$-activated, and ubiquitin-proteosome proteolytic pathways. Journal of Clinical Investigation 97 1610-1617.

White M \& Kahn C 1994 The insulin signaling system. Journal of Biological Chemistry 269 1-5.

Zamir O, Hasslegren P-O, Kunkel S, Frederick J, Higashiguchi T \& Fischer J 1992 Evidence that tumor necrosis factor participates in the regulation of proteolysis during sepsis. Archives of Surgery 127 170-174.

Received 8 October 1998

Accepted 28 April 1999 